\title{
Creating modern competitive hybrids tomato for greenhouse plants of small-volume hydroponics
}

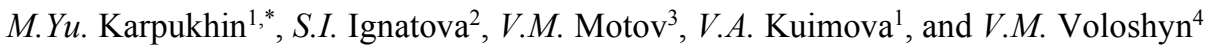 \\ ${ }^{1}$ Ural State Agrarian University, Ekaterinburg, Russia \\ ${ }^{2}$ Selection and Seed Agrofirm Ilyinichna, Moscow, Russia \\ ${ }^{3}$ Federal Agrarian Research Center of the North-East named after N.V. Rudnitsky, Kirov, Russia \\ ${ }^{4}$ National Science Center "Institute of Agriculture of the National Academy of Agrarian Sciences of \\ Ukraine", Chabany, Ukraine
}

\begin{abstract}
Study was carried out for new heterotic tomato hybrids at a modern greenhouse complex JSC "Teplichnoye" in 2016-2018, which located in the village of Sadovy, urban okryga Verkhnyaya Pyshma, Sverdlovsk region. Hybrids were included in the experimental scheme 901, $950,951,1001,12000,12002,12283,12294,12898,12899$, it was selected Holland-select "Romano " hybrid as a control for the study. Plants were studied in extended circulation of winter greenhouses in small-volume hydroponics. It was found that in the newly studied hybrids $901,950,951$, and 12283 , flowering and fruiting occurred a week earlier in comparison with the control and other variants. The most productive were hybrids 951 , $901,12283,12899$, the yields of which exceeded the control 10.5-29.2 kg. The most productive hybrid $951-78.6 \mathrm{~kg} / \mathrm{m} 2$. Due to the high individual yield, the level of profitability of the above hybrids was the highest, therefore hybrids 901, 951, 12283, 12899 can be recommended for cultivation in extended circulation of winter greenhouses of small-volume technology.
\end{abstract}

\section{Introduction}

Currently, more attention is paid to the rational human regime of raw vegetables which are rich in vitamins and other useful substances. Among the most common vegetable widespread, tomato. This plant, relatively recently was introduced into cultivation, now occupies large areas in most countries of the world. It is difficult to grow tomatoes in the fields in the Middle Urals, therefore they are grown in greenhouses in winter and spring. The selection of new varieties, more productive, is also an additional reason in providing the people with high-vitamin vegetables [1-14].

Tomatoes have high flavor and powerfully nutritional qualities: they contain vitamins, mineral salts and organic acids. They are also antidepressants, regulate the functioning of the nervous system, improve mood due to serotonin. Tomatoes have antibacterial and antiinflammatory properties due to the content of phytoncides. They were considered very

\footnotetext{
${ }^{*}$ Corresponding author: mkarpukhin@yandex.ru
} 
beneficial for the digestive system, as they improve metabolism. Tomatoes are a good diuretic for kidney and bladder diseases, help with asthenia, atherosclerosis, azotemia, and bowel disorders. Increasing tomato intake can help prevent heart disease, preserve vision, and prevent retinal changes that can cause blindness in aging. Tomatoes protect the body from the harmful effects of solar radiation [15-23].

The population of the northern regions of the country, where there is a severe lack of vitamins, is especially in need of fresh tomato fruits.

According to the Institute of Nutrition of the Russian Academy of Medical Sciences, the recommended average annual consumption of tomato is $35 \mathrm{~kg}$.

All these properties of tomato fruits make it an irreplaceable product in human life. Therefore, an increase in their production is one of the critical problems in vegetable growing. In the meantime, in the Middle Urals, fresh fruits are produced only at $0.5-0.8 \mathrm{~kg}$ per capita. And most of the fresh fruits are imported from the southern regions of the country in the summer-autumn period, and in the winter in processed form. In winter, fresh tomato fruits are imported from Turkey, Spain, Holland and other countries [24-37].

The legal basis for the development of breeding works aimed at obtaining domestic vegetable seeds of protected ground is: Decree of the President of the Russian Federation No. 350 dated July 11, 2016 "On measures to implement state scientific and technical policy in the interests of agricultural development" and the Federal Scientific and Technical agricultural development program for 2017-2025 " approved by Decree of the Government of the Russian Federation No. 996 of August 25, 2017.

The Ural State Agrarian University approved an action plan for the implementation of the Federal Target Scientific and Technical Program for the Development of Agriculture for 2017-2025, according to which, in addition to the current research infrastructure, a research, production and educational agricultural consortium was created [37-45].

\section{Experimental Part}

Study Purpose: To define the most highly productive hybrids tomato which could resistant to major diseases for the extended turnover of modern greenhouse plants.

The experiment was carried out in a modern greenhouse complex JSC "Teplichnoye", which is located in the northern part of Yekaterinburg in the village "Sadovy", at the greenhouse complex there is an administrative and production block, engineering infrastructure (boiler room, gas-water and power supply systems), an area of block-type greenhouse 4 hectares, a width of $100 \mathrm{~m}^{2}$, a length of $400 \mathrm{~m}^{2}$, equipped with a multi-circuit heating system. Cover Greenhouse - glass.

The plants are grown in hanging gutters $(30 \mathrm{~cm}$ wide) on a Rockwool substrate. Each plant is provided with a drip irrigation system. The optimal microclimate and the number of irrigations, curtains, opening and closing of transoms, are regulated by a special computer in an automated system.

The greenhouse has a platform under a common roof for loading cardboard boxes of fruits on pallets and moving them by using forklifts.

Experiment scheme

Studied hybrids:

$\begin{array}{llll}901 & 1001 & 12283 & 12899 \\ 950 & 12000 & 12294 & \text { Romano (c) } \\ 951 & 12002 & 12898 & \end{array}$

The agrotechnics in the experiment were as follows: In the light of that the annual harvest is mainly extended in the period from January to September, during this period it is 
recommended to pay more attention to plant. Agrotechnology for growing tomatoes is shown in table 1.

Table 1. The agrotechnics in the experiment.

\begin{tabular}{|c|c|}
\hline Operations & Notes \\
\hline 1 & 2 \\
\hline \multicolumn{2}{|r|}{ Seedling period } \\
\hline $\begin{array}{l}\text { Sowing was carried out on } \\
12 \text { th December in cassettes } \\
\text { with mineral wool plugs. }\end{array}$ & $\begin{array}{r}\text { The day earlier sowing, the cassettes were saturated with a mineral solution with } \\
\text { a concentration of } 2.0 \mathrm{mS} \text {. After sowing, the cassettes were covered with foil } \\
\text { until germination. }\end{array}$ \\
\hline $\begin{array}{l}\text { Picking seedlings into } \\
\text { cubes on 16th January. }\end{array}$ & $\begin{array}{l}\text { Also, the day earlier the pick, the cubes were soaked to full moisture capacity } \\
\text { with a solution with a concentration of } 2.5 \mathrm{mS} \text {, the concentration in the cassettes } \\
\text { was increased. The pick was carried out with the "overturning" of the cork against } \\
\text { the wall of the cube and sprinkled with moistened vermiculite. }\end{array}$ \\
\hline Seedling care & $\begin{array}{l}\text { There was no additional lighting during the day. The next day, additional lighting } \\
\text { was turned on. For rooting of plants, the temperature was kept at } 19-20^{\circ} \mathrm{C} \text {, then } \\
\text { decreased: in the daytime }-17-18 \text {, at night }-15-16^{\circ} \mathrm{C} \text {. As the plants grew, the } \\
\text { "arrangement" was made, the time of additional illumination was reduced, and } \\
\text { the plants were watered with a gradual increase in the concentration of the mineral } \\
\text { solution. }\end{array}$ \\
\hline \multicolumn{2}{|r|}{ Preparation period } \\
\hline $\begin{array}{l}\text { Preparing } \\
\text { greenhouses for } \\
\text { transportation and } \\
\text { planting of plants }\end{array}$ & $\begin{array}{l}\text { Lay out substrates; install droppers into the holes; hooks with twine to tie plants; } \\
\text { saturate the mats with a mineral solution }\end{array}$ \\
\hline Planting & $\begin{array}{l}\text { Plants are placed on mats next to the cut holes with drainage strips to the registers } \\
\text { and tied up. Plants are planted in mats with the first blooming brush }\end{array}$ \\
\hline \multicolumn{2}{|r|}{ Caring tomato plants during the growing season } \\
\hline Lower operations & $\begin{array}{l}\text { Removing stepchildren is carried out in the morning. The brush holders are placed } \\
\text { immediately after the brush has blossomed. When rationing, } 4 \text { fruits are left. } \\
\text { Remove the bottom leaf when brushing with fruits. Fruited brushes are cut with } \\
\text { pruning shears. Collect tomato fruits three times a week by sorting. Preventive } \\
\text { plant protection works. }\end{array}$ \\
\hline Upper operations & $\begin{array}{l}\text { Removing stepchildren along the plant stem is carried out in the morning. Brush } \\
\text { lightening only at the point of growth, leaving the "hemp", lightening the brush is } \\
\text { not allowed along the plant stem. The twisting of the plant stem is carried out in } \\
\text { the afternoon. Brush rationing for } 4 \text { fruits - after tying the hand. Leaving an } \\
\text { additional shoot with a twist, directing in front of the main shoot. Lowering the } \\
\text { plants obliquely with stapling the stem. Pinching the main stem. }\end{array}$ \\
\hline End of season & $\begin{array}{l}\text { Disinfection of plant residues. Cleaning of drainage drains, flushing of the system. } \\
\text { Trimming the stem at the root. Cutting tomato plants from a trellis, cutting into } \\
\text { parts of plant residues. Gathering mats and droppers. Thorough disinfection. }\end{array}$ \\
\hline \multicolumn{2}{|r|}{ Plant nutrition } \\
\hline During the season & $\begin{array}{l}\text { From sowing to planting and growing plants, the acidity of the nutrient solution } \\
\text { was kept within } 5.5 \text {. During the season, acidity in mat and cubes varied between } \\
5.5 \text { and } 6.0 \text {. The concentration of the nutrient solution varied depending on the } \\
\text { growth and development of plants, depending on solar radiation. Concentration } \\
\text { increased in cloudy weather. In the mats, the concentration varied from } 3.5 \text { to } 4.5 \\
\mathrm{mS} / \mathrm{cm} \text {. the composition of the nutrient solution also changed. During the } \\
\text { seedling period, the nutrient solution contains less ammonia, a higher dose of } \\
\text { calcium, and potassium and nitrogen are at the same level. As the tomato plants } \\
\text { grow and develop, after exposing the plants to the mats from the seedling } \\
\text { department, the nitrogen dose decreases, then (after the fifth cluster has flowered) } \\
\text { the doses of calcium decrease (calcium is required for the growth of the root } \\
\text { system and plant rooting) and the potassium content increases (potassium affects } \\
\text { the quality of the crop ). If there is a lack of any elements, foliar feeding is } \\
\text { performed. }\end{array}$ \\
\hline
\end{tabular}




\section{Results and Discussions}

The data of phenological observations showed that the entrances of all hybrids appeared simultaneously (Table 2).

Table 2. Data of phenological observations of the tomato plants development.

\begin{tabular}{|c|c|c|c|c|c|c|c|c|}
\hline \multirow[b]{3}{*}{ Hybrids } & \multicolumn{8}{|c|}{ Dates } \\
\hline & \multirow[b]{2}{*}{ 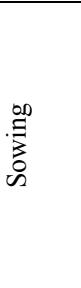 } & \multirow[b]{2}{*}{ 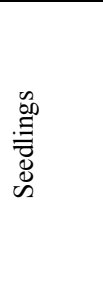 } & \multirow[b]{2}{*}{ 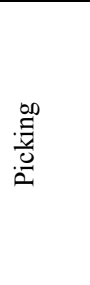 } & \multirow{2}{*}{ 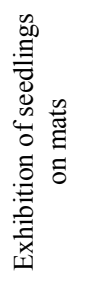 } & \multirow[b]{2}{*}{ 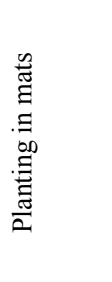 } & \multicolumn{2}{|c|}{ Start } & \multirow[b]{2}{*}{ 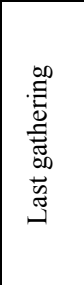 } \\
\hline & & & & & & 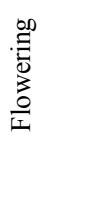 & 兽 & \\
\hline 901 & 12.12 & 22.12 & 16.01 & 22.01 & 14.03 & 02.03 & 04.05 & 07.11 \\
\hline 950 & 12.12 & 22.12 & 16.01 & 22.01 & 14.03 & 02.03 & 04.05 & 07.11 \\
\hline 951 & 12.12 & 22.12 & 16.01 & 22.01 & 14.03 & 02.03 & 04.05 & 07.11 \\
\hline 1001 & 12.12 & 22.12 & 16.01 & 22.01 & 14.03 & 02.03 & 11.05 & 07.11 \\
\hline 12000 & 12.12 & 22.12 & 16.01 & 22.01 & 14.03 & 02.03 & 11.05 & 07.11 \\
\hline 12002 & 12.12 & 22.12 & 16.01 & 22.01 & 14.03 & 02.03 & 11.05 & 07.11 \\
\hline 12283 & 12.12 & 22.12 & 16.01 & 22.01 & 14.03 & 02.03 & 11.05 & 07.11 \\
\hline 12294 & 12.12 & 22.12 & 16.01 & 22.01 & 14.03 & 09.03 & 11.05 & 07.11 \\
\hline 12898 & 12.12 & 22.12 & 16.01 & 22.01 & 14.03 & 09.03 & 11.05 & 07.11 \\
\hline 12899 & 12.12 & 22.12 & 16.01 & 22.01 & 14.03 & 09.03 & 11.05 & 07.11 \\
\hline $\begin{array}{l}\text { The } \\
\text { control }\end{array}$ & 12.12 & 22.12 & 16.01 & 22.01 & 14.03 & 07.03 & 06.05 & 07.11 \\
\hline
\end{tabular}

The data of phenological observations confirmed that the seedlings of all the studied hybrids appeared simultaneously. The picking of seedlings was carried out at the same time on 16.01, as well as planting of seedlings on 22.01. However, the planting of seedlings was not carried out immediately in a permanent place. First, for the adaptation of plants, cotton cubes were on a towel. After a month and a half, on 14th March, the tomato plants were put in a permanent place. Further observations revealed that the flowering phase in some of the hybrids began earlier - on 2nd March, in comparison with other studied hybrids by 5 days, and that's why the timing of the fruiting was different. The last harvest was at all at the same time on 07.11 .

It was found that the duration of the periods from sowing to germination for all hybrids had 10 days (Table 3 )

Table 3. The duration of the periods of passage of Phenophases in the studied varieties.

\begin{tabular}{|c|c|c|c|c|c|c|c|}
\hline \multirow[b]{2}{*}{ Varieties } & \multicolumn{7}{|c|}{ Days from sowing } \\
\hline & 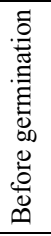 & 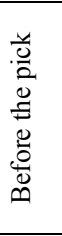 & 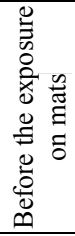 & 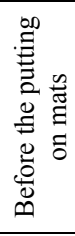 & 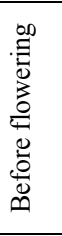 & 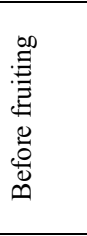 & 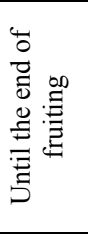 \\
\hline 901 & 10 & 35 & 41 & 92 & 81 & 143 & 330 \\
\hline 950 & 10 & 35 & 41 & 92 & 81 & 143 & 330 \\
\hline 951 & 10 & 35 & 41 & 92 & 81 & 143 & 330 \\
\hline 1001 & 10 & 35 & 41 & 92 & 81 & 148 & 330 \\
\hline 12000 & 10 & 35 & 41 & 92 & 81 & 148 & 330 \\
\hline 12002 & 10 & 35 & 41 & 92 & 81 & 148 & 330 \\
\hline 12283 & 10 & 35 & 41 & 92 & 81 & 148 & 330 \\
\hline
\end{tabular}




\begin{tabular}{|c|c|c|c|c|c|c|c|}
\hline 12294 & 10 & 35 & 41 & 92 & 86 & 148 & 330 \\
\hline 12898 & 10 & 35 & 41 & 92 & 86 & 148 & 330 \\
\hline 12899 & 10 & 35 & 41 & 92 & 86 & 148 & 330 \\
\hline Control & 10 & 35 & 41 & 92 & 84 & 145 & 330 \\
\hline
\end{tabular}

The first shoots appeared in 10 days after sowing for hybrids. Planting of seedlings was simultaneously in 35 days from sowing. On the 81 st day, some hybrids began to bloom, the rest of the studied hybrids had 5 days more. Further observations showed that fruiting also began earlier for some of the hybrids. The end of fruiting was the same for all hybrids in 330 days after sowing.

It was found that growing tomatoes in modern greenhouses with a high roof allows the installation of tall trellises for plant garters. By the method lower per week, the length of the plants in the experiment stretched from 5.5 to $8.4 \mathrm{~m}$ (Table 4).

Table 4. Height Plant of the studied hybrids.

\begin{tabular}{|c|c|c|c|c|c|c|c|c|}
\hline \multirow[b]{2}{*}{ Hybrids } & \multicolumn{8}{|c|}{ Plant height, cm } \\
\hline & 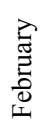 & 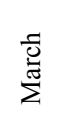 & 竞 & $\sum_{\Sigma}^{\vec{J}}$ & $\stackrel{\Xi}{\Xi}$ & $\vec{\Xi}$ & 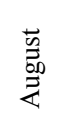 & $\begin{array}{l}\bar{d} \\
\text { है } \\
\text { है } \\
\stackrel{0}{0}\end{array}$ \\
\hline 901 & 27 & 93 & 197 & 284 & 351 & 406 & 483 & 576 \\
\hline 950 & 27 & 98 & 205 & 281 & 360 & 439 & 517 & 606 \\
\hline 951 & 33 & 92 & 216 & 296 & 381 & 451 & 528 & 626 \\
\hline 1001 & 36 & 108 & 220 & 309 & 384 & 442 & 494 & 587 \\
\hline 12000 & 36 & 103 & 205 & 284 & 369 & 467 & 568 & 664 \\
\hline 12002 & 35 & 97 & 204 & 291 & 372 & 472 & 569 & 659 \\
\hline 12283 & 28 & 89 & 186 & 274 & 339 & 411 & 507 & 606 \\
\hline 12294 & 23 & 85 & 201 & 278 & 367 & 450 & 543 & 660 \\
\hline 12898 & 25 & 86 & 185 & 260 & 355 & 427 & 517 & 622 \\
\hline 12899 & 24 & 87 & 197 & 273 & 363 & 446 & 537 & 641 \\
\hline Control & 54 & 106 & 241 & 338 & 434 & 531 & 637 & 740 \\
\hline
\end{tabular}

In the light of the experiment, it was found that the maximum length of the stem by the end of the growing season was the hybrid 12000 and equaled to $6.64 \mathrm{~m}$. The second highest was the hybrid 12294, the length of the stem of which was $6.6 \mathrm{~m}$. The stem length of the control variety Romano by the end of the growing season was $7.4 \mathrm{~m}$. It was also revealed that the hybrid 901 was the shortest, its stem length by the end of the growing season was 5.76 $\mathrm{m}$. Finally the monthly average growth of the stems of the studied hybrids varied from $0.3 \mathrm{~m}$ at the beginning and $1 \mathrm{~m}$ at the end of the growing season.

The features of the development of the leaf apparatus in the studied hybrids tomato are shown in Table 5.

Table 5. Assimilation surface of hybrids tomato.

\begin{tabular}{|c|c|c|c|c|}
\hline varieties & leaves number on & Leaf length, & \multicolumn{2}{|c|}{ Assimilation surface } \\
\cline { 4 - 5 } & the plant, pcs & $\mathrm{cm}$ & $\mathrm{M}^{2}$ & $\mathrm{C}$ Control, \% \\
\hline 901 & 119 & 40,4 & 4,81 & 53,56 \\
\hline 950 & 126 & 42,1 & 5,30 & 59,10 \\
\hline 951 & 130 & 40,5 & 5,27 & 58,66 \\
\hline 1001 & 125 & 41,2 & 5,15 & 57,38 \\
\hline 12000 & 129 & 41,2 & 5,31 & 59,21 \\
\hline 12002 & 128 & 42 & 5,38 & 59,89 \\
\hline 12283 & 118 & 41,6 & 4,91 & 54,69 \\
\hline 12294 & 121 & 39,8 & 4,82 & 53,65 \\
\hline 12898 & 129 & 43,6 & 5,62 & 62,66 \\
\hline 12899 & 132 & 39,3 & 5,19 & 57,79 \\
\hline Control & 220 & 40,8 & 8,98 & \\
\hline
\end{tabular}


The differences in the size of the leaf blade between the hybrids and $\mathrm{S}$ of the assimilation surface ranged from 4.8 to $8.9 \mathrm{~m}^{2}$ per plant.

For the length of the leaf, the differences ranged from $35 \mathrm{~cm}$ to $45 \mathrm{~cm}$. The largest number of leaves was been in hybrid 12899 it was equaled to 132 leaves, and the smallest in hybrid 12283 - 118 ones.

The advantage of the development of the root system in small-volume hydroponics is that, according to agricultural technology and adjusted nutrition, plants rarely experience lack nutrient. Nutrition comes from droppers near the roots of each plant. The dimensions of the root system are lower than on soils. The experiment in this study shows data on the characteristics of the root system persisted until the end of the growing season in a mineral cube (Table 6).

Table 6. Biometric characteristic of the root system.

\begin{tabular}{|c|c|c|}
\hline Hybrid & Weight of raw roots, $\mathrm{g}$ & volumetric mass, $\mathrm{cm}^{3}$ \\
\hline 901 & 21,2 & 10 \\
\hline 950 & 52,8 & 20 \\
\hline 951 & 61 & 40 \\
\hline 1001 & 46,6 & 40 \\
\hline 12000 & 80 & 60 \\
\hline 12002 & 71,4 & 50 \\
\hline 12283 & 75,3 & 50 \\
\hline 12294 & 73,5 & 60 \\
\hline 12898 & 83,4 & 60 \\
\hline 12899 & 55,4 & 20 \\
\hline Control & 122,8 & 100 \\
\hline
\end{tabular}

The largest mass of roots at the end of the growing season was been in the hybrid 12898 $83.4 \mathrm{~g}$, and the smallest one was $21.2 \mathrm{~g}$ in the hybrid 901 .

When comparing the volumetric mass of roots, the first was hybrids 12000, 12294 and 12898 together, the volumetric mass of which was $60 \mathrm{~cm}^{3}$, the second was, in the control hybrid Romano, the volumetric mass was $100 \mathrm{~cm}^{3}$.

One character of growing tomato plants in small-volume hydroponics is high yields, and that what has been proven in this study. Productivity for the growing season until October, depending on the hybrid, $\mathrm{kg} / \mathrm{m}^{2}$ and the average weight of fruits are shown in Table 7.

Table 7. Productivity and weight of tomato fruits.

\begin{tabular}{|c|c|c|c|c|}
\hline \multirow{2}{*}{ Hybrid } & \multicolumn{2}{|c|}{ Fruit weight, $\mathrm{g}$} & \multicolumn{2}{c|}{ Productivity, $\mathrm{kg} / \mathrm{m}^{2}$} \\
\cline { 2 - 5 } & Weight, $\mathrm{g}$ & $\% \mathrm{C}$ control & Productivity & $\% \mathrm{C}$ control \\
\hline 901 & 104 & 49,5 & 69,9 & 141,5 \\
\hline 950 & 120 & 57,2 & 39,5 & 79,9 \\
\hline 951 & 250 & 119,1 & 78,6 & 159,1 \\
\hline 1001 & 390 & 185,7 & 39,3 & 79,5 \\
\hline 12000 & 124 & 59,1 & 41,7 & 84,4 \\
\hline 12002 & 120 & 57,2 & 36,7 & 74,3 \\
\hline 12283 & 105 & 50 & 68,2 & 138,1 \\
\hline 12294 & 120 & 57,2 & 38,3 & 77,5 \\
\hline 12898 & 115 & 54,8 & 48,1 & 97,4 \\
\hline 12899 & 110 & 52,4 & 59,9 & 121,3 \\
\hline Control & 210 & - & 49,4 & - \\
\hline
\end{tabular}

According to the results of the study, the most productive was the hybrid $951-78.6 \mathrm{~kg} /$ $\mathrm{m}^{2}$, the second in productivity was the hybrid $901-69.9 \mathrm{~kg} / \mathrm{m}^{2}$, with HCP05 $=0.6 \mathrm{~kg} / \mathrm{m}^{2}$ the difference was significant. The control "Romano", according to the study, was in 5th place, its productivity was $49.4 \mathrm{~kg} / \mathrm{m}^{2}$. 
Economic efficiency is the ratio of the effect which obtained and the costs. In agriculture, efficiency is an increase in output with lower costs of all types of resources used per unit of output. The efficiency of agricultural production will increase in direct relationship to the increase in crop yields at constant costs.

The economic efficiency showed (Table 8) that hybrids 951, 901 and 12283 are economically feasible and most efficient to grow than of all the studied hybrids.

Table 8. Determination of economic efficiency.

\begin{tabular}{|c|c|c|c|c|c|c|}
\hline Options & $\begin{array}{c}\text { Production } \\
\text { costs for } 1 \mathrm{~m}^{2}, \\
\text { rub }\end{array}$ & $\begin{array}{c}\text { Productivity } \\
, \mathrm{kg} / \mathrm{m}^{2}\end{array}$ & $\begin{array}{c}\text { Cost of 1 } \\
\mathrm{kg}, \mathrm{rub}\end{array}$ & $\begin{array}{c}\text { Revenue, } \\
\text { rub } / \mathrm{m}^{2}\end{array}$ & $\begin{array}{c}\text { Profit, rub / } \\
\mathrm{m}^{2}\end{array}$ & Profitability\%, \\
\hline 901 & 1646,55 & 69,9 & 23,5 & 6291 & 4644,45 & 282 \\
\hline 950 & 1646,55 & 39,5 & 41,6 & 3555 & 1908,45 & 115,9 \\
\hline 951 & 1646,55 & 78,6 & 20,9 & 7074 & 5427,45 & 329,6 \\
\hline 1001 & 1646,55 & 39,3 & 41,9 & 3537 & 1890,45 & 114,81 \\
\hline 12000 & 1646,55 & 41,7 & 39,4 & 3753 & 2106,45 & 127,93 \\
\hline 12002 & 1646,55 & 36,7 & 44,8 & 3303 & 1656,45 & 100,6 \\
\hline 12283 & 1646,55 & 68,2 & 24,1 & 6138 & 4491,45 & 272,7 \\
\hline 12294 & 1646,55 & 38,3 & 42,9 & 3447 & 1800,45 & 109,3 \\
\hline 12898 & 1646,55 & 48,1 & 34,2 & 4329 & 2682,45 & 162,9 \\
\hline 12899 & 1646,55 & 59,9 & 27,4 & 5391 & 3744,45 & 227,4 \\
\hline Control & 1646,55 & 49,4 & 33,4 & 4446 & 2799,45 & 170 \\
\hline
\end{tabular}

\section{Conclusion}

1. According to the requirements of the state variety testing, we did the experiment of testing new hybrids tomato. The experiment was carried out in a production environment at a modern greenhouse complex.

2. The data of phenological observations established that the appearance of seedlings in all studied hybrids was simultaneous, but in hybrids 901, 950, 951 and 12283 flowering and fruiting occurred earlier than 7, 7 days, respectively.

3. Cultivation of hybrids tomato in one stem in modern hydroponic greenhouses showed that the maximum length of the stem by the end of the growing season of the studied hybrids was in the hybrid 12000 and equaled to 6.64 meters.

4. By comparing the mass of the root system, the first was the control variant Romano 122.8 g. and for the studied hybrids $12898-83.4 \mathrm{~g}$, and the hybrid 901 was the smallest and amounted to $21.2 \mathrm{~g}$.

5. The highest yield, which obtained from March to November, was in the hybrid $951-78.6$ $\mathrm{kg} / \mathrm{m}^{2}$, which is $29.2 \mathrm{~kg} / \mathrm{m}^{2}$ bigger than the Romano control variant.

6. In hybrids 951, 901 and 12283 had high pure income, low cost and high level of profitability, due to high individual yield.

\section{References}

1. B.K. Abramov, Climate and tomato culture, 603 (Leningrad: Gidrometeoizdat, 1987)

2. E.A. Aliev, Growing vegetables in hydroponic greenhouses, 160 (K, Harvest, 1985) 
3. A.B. Alpatiev, Bulletin. Section Agronomy, 148, 13-16 (1985)

4. A.V. Alpatiev, Tomatoes, 304 (M., Kolos, 1981)

5. Sh.G. Bekseev, Growing early tomatoes, 200 (L, Kolos, 1975)

6. A.S. Bolotskikh, Tomatoes, 318 (Kharkov, Folio, 2003)

7. D.D. Brezhnev, Tomatoes, 320 (Leningrad, Kolos, 1964)

8. W.G. Burton, Physiology of ripening and storage of food crops, 359 (M., Agropromizdat, 1985)

9. C.B. Vaschenko, Greenhouse vegetable growing, 224 (Moscow, Kolos, 1974)

10. S.F. Gavrish, Tomatoes, 70 (M., Rosselkhozizdat. 1987)

11. V.R. Gunther, Bulletin of agricultural, science of Kazakhstan, 11, 64-76 (1980)

12. B.A. Dospekhov, Field experiment technique, 416 (M., Kolos, 1979)

13. A.A. Zhuchenko, Tomato genetics, 663 (Chisinau, Shtiintsa, 1973)

14. A.A. Zhuchenko, Ecological genetics of cultivated plants, 587 (Chisinau, Shtiintsa, 1980)

15. S.I. Ignatova, Gavrish, 6, 18-20 (2001)

16. V.M. Markov, M.K. Khaev, Vegetable growing, (M., Selkhozgiz, 1953)

17. V.M. Markov, Vegetable growing, (M., Kolos, 1974)

18. G.S. Osipova, Protected ground vegetable growing: a tutorial, 288 (SPb, Prospectus of Science, 2010)

19. A.N. Paponov, Phenological variability of traits of vegetable plants in connection with technology and agroclimatic growing conditions, 30 (M., TSKHA 1985)

20. G.F. Popov, Greenhouse facilities, 173 (M., Rosselkhozizdat, 1986)

21. G.I. Tarakanov, Vegetable growing of protected soil, 420 (Moscow, Kolos, 1982)

22. K.A. Chusovitina, The reaction of tomato varieties to green cuttings when growing seedlings in spring greenhouses, (2011)

23. K.A. Shuin, Vegetable crops, 384 (Mn., Urajay, 1974)

24. V.I. Edelstein, Vegetable growing, (M. State, Selkhozgiz, 1951)

25. A.V. Yurina, Vegetable growing in the Urals, 366 (1969)

26. E.A. Aliev., Yu.A. Dyukarev, B.V. Latenko, Growing vegetables in greenhouses without soil, 31-37 (M., Kolos, 1965)

27. R.Kh. Bekov, A.N. Ataev, Assessment of plant growth and development, keeping quality of tomato fruits grown from seeds of high-growing varieties and hybrids. Improvement of technologies of cultivation of vegetables, 190-196 (Reports of TSKhA, 1981)

28. E.N. Belogubova, A.M. Vasiliev, L.S. Gil, A.I. Pashkovsky, A.V. Prilipka, L.T. Sulima, V.I. Chernyshenko, O.V. Shcherbenko, Modern indoor and outdoor vegetable growing, 523 (Zh., PE, Ruta, 2007)

29. K.A. Britikov., I.A. Musatova, Plant physiology 480 (M., Kolos, 1964)

30. Z.S. Vasyaeva, A.V. Popov, I.I. Bagrova, Growing tomatoes in film greenhouses, 55 (Lenizdat, 1979)

31. S.F. Gavrish, E.A. Sysina, TSKHA, 261, 83 (1980)

32. N.P. Gaenko, D.O. Lebl, Greenhouse vegetable growing on low-volume hydroponics, 13-18 (M, Agropromizdat, 1985) 
33. R.G. Zaripov, A.R. Shaikhislamova, Vegetable growing and greenhouse economy, 10, 14-17 (2006)

34. E.S. Karataev, V.E. Sovetkina, Vegetable growing, 272 (M., Kolos, 1984)

35. V.P. Koksharov, A.V. Yurina, Recommendations for the cultivation of vegetables and potatoes in the Sverdlovsk region for 1978-1980, (Ural Research Institute of Agriculture, 1978)

36. E.V. Kolobkov, P.A. Postnikov, N.A. Lapteva, Plant protection in the Middle Urals, State Scientific Institution Ural Research Institute of Agriculture of the Russian Agricultural Academy, 184 (Yekaterinburg, 2012)

37. H. Simitchiev, V. Kanazirskaya, K. Miliev, Greenhouse vegetable growing on lowvolume hydroponics, 136 (M, Agropromizdat, 1985)

38. G.I. Tarakanov, V.D. Mukhin, K.A. Shuin, N.V. Borisov, V.V. Klimov, M.A. Nikiforov, V.A. Skachko, I.G. Tarakanov, M.S. Holodetsky, Vegetable growing, (M. Kolos, 2002)

39. V.A. Shkalikov, O.O. Beloshapkina, D.D. Bukreev, Protection of plants from diseases, 255 (M., Kolos, 2003)

40. A.V. Yurina, L.G. Mamonova, G.F. Reshetnikova, L.A. Kardashina, E.V. Kolobkov, Z.G. Ilyinykh, A.N. Belonogov, A.A. Ivin, R.A. Bullakh, E.F. Markin, L.K. Khrenova, P.V. Kharchenko, V.G. Yarkova, Greenhouse vegetable growing in the Urals, 192 (Sverdlovsk, Middle-Ural, 1979)

41. A.V. Yurina, L.G. Mamonova, L.A. Kardashina, G.F. Reshetnikova, N.A. Menkova, A.V. Meshcherina, P.N. Khudorozhkova, V.G. Suzan, V.V. Smertin, T.M. Uvina, S.F. Orlova, T.A. Kugaevskaya, Z.G. Ilinykh, M.P. Matern, A.N. Belonogov, V.V. Belonogova, G.S. Shorokhova, G.L. Ryabtseva, V.A. Komleva, Greenhouse vegetable growing, 208 (Sverdlovsk, Middle-Ural, 1989)

42. R. Menary, Y. Staden, Austral. Y. Plant Physiol, 3(2), 205 (1976)

43. C. Rash, P. Karlsen, Tomatkvalitet, 125(14), 380 (1980)

44. N. Stenvers, H. Stok, Cartenbauwissen-schaft, 41(4), 167-170 (1976)

45. N.M. Velizhanov, Agrarian Bulletin of the Urals, 10(201)б 16-21 (2020) DOI: 10.32417/1997-4868-2020-201-10-16-21 (In Russian) 